\title{
Effect of selenium and vitamin E supplementation on reproductive performance of young boars
}

\begin{abstract}
The studies were carried out on 40 young boars of the synthetic line 990 . On their 70 days of age, the boars were divided into two groups; the control group received $0.2 \mathrm{mg}$ Se and $30 \mathrm{mg}$ vitamin $\mathrm{E}$ while the experimental group received $0.5 \mathrm{mg} \mathrm{Se}+60 \mathrm{mg}$ vitamin E per $1 \mathrm{~kg}$ of feed mixtures. The feeding test was carried on from 70 days until 180 days of age. During the experiment the boars were subjected to live evaluations, i.e. testes volume, libido level, semen characteristics, as well as selenium concentration and glutathione peroxidase (GSHPx) activity in blood serum and seminal plasma. The boars of the experimental group, compared with the control, showed significantly $(\mathrm{P} \leq 0.05)$ higher sperm concentration and total sperm count, significantly lower $(\mathrm{P} \leq 0.05)$ percentage of spermatozoa with major or minor morphological changes, elevated $(\mathrm{P} \leq 0.05)$ percentage of spermatozoa with normal acrosome, and significantly higher $(\mathrm{P} \leq 0.01)$ ORT values. GSH-Px activity was higher $(\mathrm{P} \leq 0.05)$ in seminal plasma of the control group boars.
\end{abstract}

Key Words: selenium, vitamin E, boars, reproductive performance

\section{Zusammenfassung}

Titel der Arbeit: Einfluss eines Selen- und Vitamin-E-Zusatzes auf die Reproduktionsleistung von Jungebern

Die Untersuchungen wurden an 40 Jungebern der synthetischen Linie 990 durchgeführt. Am 70. Lebenstag wurden die Tiere in zwei Gruppen mit folgendem Gehalt an Selen und Vit. E im Futter geteilt: Kontrollgruppe 0,2 $\mathrm{mg}$ Se und $30 \mathrm{mg}$ Vit. E sowie Versuchsgruppe $0,5 \mathrm{mg} \mathrm{Se}+60 \mathrm{mg}$ Vit. E je $1 \mathrm{~kg}$ Mischfutter. Der Fütterungsversuch erstreckte sich vom 70. bis zum 180. Lebenstag der Tiere. Im Experiment wurden bestimmt: Index der Eigenleistungsprüfung, Hodenvolumen, Geschlechtsaktivität, Spermaqualitätsmerkmale, Selengehalt und GSH-Px-Aktivität im Blutserum und Spermaplasma. Die Jungeber in der Versuchsgruppe unterschieden sich im Vergleich mit den Tieren in der Kontrollgruppe durch signifikant höhere $(p \leq 0,05)$ Spermienkonzentration und Gesamtzahlen der Spermien im Ejakulat, signifikant geringeren $(\mathrm{p} \leq 0,05)$ Anteil an morphologisch veränderten Spermien, signifikant höherem $(\mathrm{p} \leq 0,05)$ Anteil an Spermien mit intaktem Akrosom sowie signifikant höheren ORT-Werten $(p \leq 0,05)$. Die GSH-Px-Aktivität im Spermaplasma war höher $(p \leq 0,05)$ als in der Kontrollgruppe.

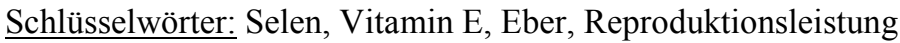

\section{Introduction}

Selenium (Se) is an integral component of the enzyme glutathione peroxidase (GSHPx). Physiological function of this enzyme have bean yet preciselly determined. Between the GSH-Px activity in seminal plasma and semen quality not found a clear relationship (LASOTA, 2002). The primary role this enzyme is detoxifies lipid peroxides and provides protection of cellular and subcellular membranes against peroxide damage. Thus, the mutual sparing effect of selenium and vitamin $\mathrm{E}$ stems from their shared antiperoxidant roles (KRSKA et al., 2001). GSH-Px is present both in a number of tissues and in the body fluids. Its high activity has been observed both in the organs of the reproductive system and in the fluids secreted thereby (SAARANEN et al., 1989). GSH-Px existing in seminal plasma is probably first of all 
synthetised in accessory sexuale glands, whereas activity of this enzyme in mature sperm is low (SMITH et al., 1979).

Besides many other functions, selenium and vitamin $\mathrm{E}$ are of great importance in reproductive processes. Female hyposelenosis is accompanied by retained placenta, disturbances in uterus involution and in ovarian functions, ovarian cysts, decreased fertilization rates, abortions, stillbirths, reduced litter size and decreased piglet survivability, inflammatory states of the uterus and Mastitis Metritis Agalactia syndrome in sows (CHAVEZ and PATTON, 1986; WANDURSKI, 1990; DEMBIŃSKI et al., 1992).

Selenium also regulates male reproductive processes. High concentration of Se in testes and epididymides of the boars implies that his element is essential for the process of production and maturation of spermatozoa (HEIMANN et al., 1984; SAARANEN et al., 1989; MARIN-GUZMAN et al., 1997). Selenium is a component of mitochondrial capsule selenoprotein, which maintains the stability of spermatozoa mitochondria (KLEENE, 1993; MARIN-GUZMAN et al., 1997). Studies carried out on males belonging to various species of the farm animals have shown the positive influence of selenium on semen quality, especially on the concentration, vitality, mobility and morphological defects of spermatozoa (LIU et al., 1982; UDAŁA et al., 1995; MARIN-GUZMAN et al., 1997, 2000).

On the contrary, other studies demonstrated that an addition of selenium to diet did not improve the semen quality of boars (SEGERSON et al., 1981; HENSON et al., 1983). Probably, selenium was not deficient in the animals in those studies and therefore no influence was observed of the element on the reproductive processes of the males. This suggestion has a confirmation in the studies by HEIMANN et al. (1984).

So far, selenium requirements have not been precisely established either for swine or for other livestock animals. According to the NATIONAL RESEARCH COUNCIL (1998) or the NORM OF PIGS NUTRITIONS (1993), selenium requirements of swine ranges between 0.1 and $0.3 \mathrm{mg}$ per $1 \mathrm{~kg}$ of ration. In the European Union, $0.5 \mathrm{mg}$ of Se per $1 \mathrm{~kg}$ of ration is considered as a safe and legally acceptable level. The aim of the present paper is to estimate the influence of increased addition of selenium and vitamin $\mathrm{E}$ on reproductive performance of young boars.

\section{Material and methods}

The studies were carried out at the State Center of Pig Hybridization in Poland on the 40 young boars of the 990 synthetic line. The boars were fed on the same diet from 30 to 70 days of age. At 70 days, the boars were distributed into two groups (control and experimental). In each group there were 20 boars. The alocation to the groups was made with analogues method, i.e. from one litter one boar was asigned to a group. A feeding test was carried out from 70 to 180 days of age. During the feeding test the boars of the Control group were fed on standard diet, which contained $0.2 \mathrm{mg}$ Se and $30 \mathrm{mg}$ vitamin E per $1 \mathrm{~kg}$. The Experimental group received $0.5 \mathrm{mg}$ Se and $60 \mathrm{mg}$ vitamin $\mathrm{E}$ per $1 \mathrm{~kg}$ of the ration. The participation of other components in both mixtures (control and experimental) was the same. The boars were housed in individual pens measuring $1 \times 2 \mathrm{~m}$, flooring was combination of solid concrete and slats (approximately 60:40). Water was provided for ad libitum and standarized feeding was applied. The daily feed ration was gradually increased along with the increasing body waight (from $1 \mathrm{~kg}$ per day at 70 days to $3.5 \mathrm{~kg}$ / day at 180 days of age and during the 
semen collection). Chemical composition and nutritive value of the diets are given in Table 1.

Table 1

Chemical composition and nutritive value of complete mixtures (in $1 \mathrm{~kg}$ ) (Chemische Zusammensetzung und Futterwert der Futtermischung (je $1 \mathrm{~kg}$ ))

\begin{tabular}{lcc}
\hline \multicolumn{1}{c}{ Item } & & Mixtures \\
& & Experimental \\
\hline Metabolizable energy (MJ) & Control & 12.8 \\
Dry matter (g) & 12.8 & 878 \\
Crude ash (g) & 883 & 60.3 \\
Crude protein (g) & 55.2 & 181 \\
Ether extract (g) & 180 & 19.1 \\
Crude fibre (g) & 22.5 & 26.7 \\
N-free extractives (g) & 27.0 & 591 \\
Lysine (g) & 598 & 9.7 \\
Methionine (g) & 9.6 & 3.5 \\
Methionine+cystine (g) & 3.4 & 6.0 \\
Threonine (g) & 6.1 & 6.6 \\
Vitamin A (j.m) & 6.3 & 7700 \\
Vitamin E (mg) & 7700 & 60.0 \\
Selenium (mg) & 30.0 & 0.53 \\
\hline
\end{tabular}

Calculated from Polish Swine Feeding Standards (1993).

At age of 70 and 180 days the testes were measured and their volume was established (YOUNG et al., 1986). The selection index considering daily gain till 180 days of age was estimated for the boars, and the percentage carcass meatiness was ultrasonically probed at 180 day of age. The semen collection began at 180 days of age and was continued to gain of standard value semen of young boars (according to Polish norm). When semen gained standard value, there were 40 ejaculates evaluated, the one ejaculate from each boar. During the semen collection, the animal sexual activity was evaluated using the number of leaps and the time elapsed to effective mounting, as well as the time of ejaculation.

Immediately after the collection and filtration of ejaculate, its following characteristics were determined: ejaculate volume, percentage of motile spermatozoa, concentration of spermatozoa in $1 \mathrm{~cm}^{3}$ (cytometric method in Bürker's chamber), and total number of spermatozoa in ejaculate.

The minor and major morphological changes of the semen (BLOM, 1981) and the grade of acrosome defects (PURSEL et al., 1972) were determined in the preparatins. The osmotic resistance test (ORT) of acrosomal membranes was performed according to SCHILLING and VENGUST (1987). In seminal plasma obtained by centrifugation of the fluid fraction of the semen, the content of selenium as well as the activity of GSH-Px and aspartate aminotransferase (AspAT) were determined. Prior to the analyses, the plasma was stored at $-20^{\circ} \mathrm{C}$.

At 180 days of age, blood from jugular vein was collected and, after centrifugation, the serum was frozen at $-20^{\circ} \mathrm{C}$.

GSH-PX activity in serum and seminal plasma according to PAGLIA and VALENTINE (1967). The activity of AspAT was measured with the kinetic method, and AspAT activity was converted as per $1 \times 10^{9}$ of spermatozoa. The selenium concentrations in the feed, blood serum, and seminal plasma were determined with the fluorometric method according to WATKINSON (1966). 
The basic nutrient concentrations in the feeds were determined with standard methods, and amino acids were measured using an automatic analyser (Beckman Instruments Inc.).

The data were statistically analysed using Statistica PL software, by means of one-way analysis of variance.

\section{Results}

The results presented in Table 2 demonstrate that the boars of both control and experimental groups achieved similar levels of the selection index (122 and 116 pts.). On the moment of starting the experiment (at 70 days of age), the boars had similar volume of both testes. At 180 days of age the volume testes of young boars of control group shaped $625 \mathrm{~cm}^{3}$ and the experimental group $654 \mathrm{~cm}^{3}$. The differences found between the groups were, however, statistically non-significant. The time mounting upon phantom, number of mounts and time of ejaculation in both groups of boars were similar.

\section{Table 2}

Testes volume, sexual activity and selection index of young boars ( $\mathrm{n}=20$ per group) (Hodenvolumen, Merkmale der Geschlechtsaktivität, Selektionsindex von Jungebern ( $n=20$ je Gruppe))

\begin{tabular}{|c|c|c|c|}
\hline \multirow{2}{*}{ Traits } & \multicolumn{3}{|c|}{ Groups } \\
\hline & & Control & Experimental \\
\hline \multicolumn{4}{|l|}{ Volume of both testes $\left(\mathrm{cm}^{3}\right)$} \\
\hline \multirow[t]{2}{*}{ - at 70 days of age } & $\bar{x}$ & 11.9 & 12.1 \\
\hline & $\mathrm{s}$ & 5.4 & 3.0 \\
\hline \multirow[t]{2}{*}{ - at 180 days of age } & $\bar{x}$ & 625 & 654 \\
\hline & $\mathrm{s}$ & 118 & 176 \\
\hline \multirow[t]{2}{*}{ Time mounting upon phantom (s) } & $\bar{x}$ & 330 & 312 \\
\hline & $\mathrm{s}$ & 136 & 111 \\
\hline \multirow[t]{2}{*}{ Number of mounts } & $\bar{x}$ & 1.6 & 1.5 \\
\hline & $\mathrm{s}$ & 0.7 & 0.7 \\
\hline \multirow[t]{2}{*}{ Time of ejaculation (s) } & $\bar{x}$ & 179 & 180 \\
\hline & $\mathrm{s}$ & 31.5 & 35.1 \\
\hline \multirow[t]{2}{*}{ Selection index (pts) } & $\bar{x}$ & 122 & 116 \\
\hline & $\mathrm{s}$ & 9.8 & 10.2 \\
\hline
\end{tabular}

The semen traits of young boars presented in Table 3. The semen of the experimental group boars showed significantly higher $(\mathrm{P} \leq 0.05)$ sperm concentration and total sperm count compared to the control group. The numbers of spermatozoa with major or minor morphological changes as well as with defective acrosomes was lower in the ejaculates of the experimental boars than in those of the control boars, respectively: $3.5 \%, 4.8 \%$ and $6 \%$. The differences were statistically significant.

The values of the osmotic resistance test (ORT) were by $13 \%$ higher $(\mathrm{P} \leq 0.01)$ in the semen of the experimental group of boars, which indicates better quality of their semen.

AspAT activity in seminal plasma of the experimental group boars was, as converted to $10^{9}$ sperm, by $53 \mathrm{mU}$ lower than that in seminal plasma of the control group boars. The difference between the groups was, however, non-significant. Selenium concentration and GSH-Px activity (Table 3) in blood serum of the boars receiving elevated levels of selenium and vitamin $\mathrm{E}$ in the ration were by approx. $6 \%$ higher 
compared to the control boars, which had been fed on standard mixture with a lower amount of selenium + vitamin E. The differences between the groups were, however, non-significant. The concentration of this microelement in seminal plasma of the experimental group was by $16 \%$ higher $(\mathrm{P} \leq 0.05)$ and $\mathrm{GSH}-\mathrm{Px}$ activity by $32 \%$ lower $(\mathrm{P} \leq 0.05)$ compared to the control group.

Table 3

Semen traits, selenium (Se) content and activity of glutathione peroxidase in the semen plasma and blood plasma of young boars (Spermamerkmale, Selengehalt sowie GSH-Px-Aktivität im Spermaplasma und Blutserum von Jungebern)

Traits

Groups

Control Experimental

\begin{tabular}{|c|c|c|c|}
\hline \multirow[t]{2}{*}{ Ejaculate volume after filtration $\left(\mathrm{cm}^{3}\right)$} & $\bar{x}$ & 106 & 109 \\
\hline & $\mathrm{s}$ & 38.4 & 10.9 \\
\hline \multirow{2}{*}{ Motile spermatozoa (\%) } & $\bar{x}$ & 70.8 & 74.6 \\
\hline & $\mathrm{S}$ & 6.1 & 6.1 \\
\hline \multirow[t]{2}{*}{ Concentration of spermatozoa $\left(\mathrm{n} \times 10^{6} / \mathrm{cm}^{3}\right)$} & $\bar{x}$ & $191 \mathrm{a}$ & $240 b$ \\
\hline & $\mathrm{s}$ & 48.1 & 81.9 \\
\hline \multirow[t]{2}{*}{ Total sperm count $\left(\mathrm{n} \times 10^{9}\right)$} & $\bar{x}$ & $20.2 \mathrm{a}$ & $26.2 b$ \\
\hline & $\mathrm{s}$ & 8.0 & 9.3 \\
\hline \multirow[t]{2}{*}{ Spermatozoa with major defects (\%) } & $\bar{x}$ & $11.0 \mathrm{a}$ & $7.5 b$ \\
\hline & $\mathrm{S}$ & 5.0 & 5.9 \\
\hline \multirow[t]{2}{*}{ Spermatozoa with minor defects (\%) } & $\bar{x}$ & $14.0 \mathrm{a}$ & $9.2 b$ \\
\hline & $\mathrm{s}$ & 6.9 & 5.1 \\
\hline \multirow[t]{2}{*}{ Spermatozoa with normal acrosome (\%) } & $\bar{x}$ & $85 \mathrm{~A}$ & $91 \mathrm{~B}$ \\
\hline & $\mathrm{s}$ & 9.3 & 5.0 \\
\hline \multirow[t]{2}{*}{ Osmotic resistance test - ORT $(\%)$} & $\bar{x}$ & $56 \mathrm{~A}$ & $69 \mathrm{~B}$ \\
\hline & s & 9.2 & 13.4 \\
\hline \multirow[t]{2}{*}{ AspAT (mU/10 $0^{9}$ spermatozoa) } & $\bar{x}$ & 119 & 66 \\
\hline & $\mathrm{s}$ & 72.0 & 30.3 \\
\hline \multirow[t]{2}{*}{ Se in semen plasma $(\mu \mathrm{g} / \mathrm{ml})$} & $\bar{x}$ & $0.043 \mathrm{a}$ & $0.051 b$ \\
\hline & $\mathrm{s}$ & 0.02 & 0.02 \\
\hline \multirow[t]{2}{*}{ GSH-Px in semen plasma (U/ml) } & $\bar{x}$ & $0.317 \mathrm{a}$ & $0.240 \mathrm{~b}$ \\
\hline & $\mathrm{s}$ & 0.146 & 0.85 \\
\hline \multirow[t]{2}{*}{ Se in blood plasma $(\mu \mathrm{g} / \mathrm{ml})$} & $\bar{x}$ & 0.264 & 0.281 \\
\hline & $\mathrm{s}$ & 0.049 & 0.045 \\
\hline \multirow[t]{2}{*}{ GSH-Px in blood plasma (U/ml) } & $\bar{x}$ & 4.01 & 4.29 \\
\hline & $\mathrm{s}$ & 1.4 & 1.2 \\
\hline
\end{tabular}

Statistical significance: $\mathrm{a}, \mathrm{b}-\mathrm{P} \leq 0.05 ; \mathrm{A}, \mathrm{B}-\mathrm{P} \leq 0.01$

\section{Discussion}

Application of elevated amount of $\mathrm{Se}+$ vitamin $\mathrm{E}$ positively influenced their testes size at 180 days of age. The experimental group boars exhibited by $29 \mathrm{~cm}^{3}$ larger total testes volume compared with those of the control group. No clear results were obtained while analysing an effect of selenium on testes size. WALLACE et al. (1983) observed underdevelopment of testes and reduced production of spermatozoa in mice receiving selenium-deficient diets. MARIN-GUZMAN et al. (1997), on the other hand, observed very similar sizes of testes in boars that had been fed on rations containing 0 and $0.5 \mathrm{ppm}$ of Se during their growth.

Increasing selenium addition from 0.2 to $0.5 \mathrm{mg}$ and vitamin $\mathrm{E}$ from 30 to $60 \mathrm{mg}$ per 1 $\mathrm{kg}$ of ration did not influence libido of the boars. Thus, reports by other authors that 
selenium is beneficial to boars' sexual activity (BRONICKI and DEMBIŃSKI, 1991) has not been confirmed in our experiment.

Elewated addition of selenium and vitamin $\mathrm{E}$ has positive influence of the concentration and total sperm count in the ejaculates of young boars. Morphological evaluation of spermatozoa in the ejaculates of the boars demonstrated that an addition of $0.5 \mathrm{mg} \mathrm{Se}+60 \mathrm{mg}$ vitamin $\mathrm{E}$ to $1 \mathrm{~kg}$ of feed reduced considerably the percentage of morphologically changed spermatozoa. A positive effect of selenium on sperm concentration and morphology has been confirmed also by other authors (LIU et al., 1982; MARIN-GUZMAN et al., 1997). It was demonstrated in studies on boars (MARIN-GUZMAN et al., 1997, 2000a) that adding vitamin E alone in an amount of 220 $\mathrm{IU} / \mathrm{kg}$ of ration was of little effect in relation to morphological changes in spermatozoa or other traits. This implies that both antioxidants, Se + vitamin E, which act synergistically, should be administered jointly (GABRYSZUK, 1994).

The values of the osmotic resistance test (ORT) were significantly higher in the semen of the experimental group of boars, which indicates better quality of their semen. The ORT count on evaluation of spermatozoa acrosomes state in different osmotic pressures. The test indicate about semen quality and its fertilising capacity. A strong, positive correlation between ORT results and semen fertilising capacity (SCHILLING and VENGUST, 1987; UDAŁA et al., 1996).

The aspartate aminotransferase (AspAT) activity in seminal plasma indicates that the spermatozoa cell membrane damage. As a consequence of such defect, AspAT leaks from the spermatozoa to the plasma (CIERESZKO et al., 1992). A comparison of AspAT activity in seminal plasma of the boars in particular groups indicates that an addition of $0.5 \mathrm{mg} \mathrm{Se}+60 \mathrm{mg}$ vitamin $\mathrm{E}$ per $1 \mathrm{~kg}$ of ration prevented cellular membrane damage in spermatozoa.

The results of our studies have confirmed those reported by other authors (SEGERSON et al., 1981) that selenium prevents structural damage of spermatozoan cellular membranes.

Selenium concentration and GSH-Px activity in blood serum of the boars control and experimental group were similar. Other authors have not found a clear relationship between the quantity of this microelement in feeding ration and its concentration as well as GSH-Px activity in porcine blood serum. MARIN-GUZMAN et al. (1997) found statistically significant increase in selenium content and GSH-Px activity in blood serum of boars obtaining $0.5 \mathrm{ppm}$ Se in ration during growing. MAHAN and PARRETT (1996), on the other hand, who applied 0.1, 0.3 and $0.5 \mathrm{ppm}$ Se in the form of sodium selenite in the ration found very similar selenium concentration and GSHPx activity in the blood serum of growing and adult pigs.

Elevated addition of selenium from $0.2 \mathrm{mg}$ to $0.5 \mathrm{mg}$ and vitamin E from $30 \mathrm{mg}$ to 60 $\mathrm{mg}$ per $1 \mathrm{~kg}$ of the ration decreased statistically significant GSH-Px activity in experimental group, despite the fact that the latter exhibited much better semen quality than the boars of the control group. LASOTA (2002) not found a clear relationship between the GSH-Px activity in seminal plasma and semen quality. The results obtained confirm the suggestion that most selenium in an organism occurs in proteins other than, as it was once assumed, in GSH-Px (PEHRSON, 1994). Higher selenium concentration in seminal plasma of the experimental group boars enables a conclusion that the element is a component of other selenoproteins that positively influence the boars' reproductive performance. New selenoproteins have been identified over the 
recent years, e.g. selenoprotein-P, which is beneficial to animal reproduction (ARTHUR, 1994).

\section{Conclusion}

Increased addition of selenium and vitamin $\mathrm{E}$ to balanced feed mixtures fed to growing boars, from the currently recommended standard amounts $(0.2 \mathrm{mg} \mathrm{Se}+30 \mathrm{mg}$ vitamin E per $1 \mathrm{~kg}$ ) to $0.5 \mathrm{mg} \mathrm{Se}+60 \mathrm{mg}$ vitamin $\mathrm{E}$ per $1 \mathrm{~kg}$ has a minor effect on testes size and libido traits of the boars; whereas it significant positively influences both quantitative and qualitative semen traits.

\section{References}

ARTHUR, J.R.:

The biochemical function of selenium: relationships to thyroid metabolism and antioxidant systems. The Rowett Research Institute Annual report 1993. The Rowett Research Institute, Aberdeen, Scotland, 1994

BLOM, E.:

Studies on seminal vesiculitis in the bull: II. Proposal for a new classification of the spermiogram. Medycyna Wet., Lublin, Poland, 4 (1981), 239-242

BRONICKI, M.; DEMBIŃSKI, Z.:

The role of selenium in reproduction of pigs. Medycyna Wet., Lublin, Poland, 10 (1991), 464-465

CHAVEZ, E.R.; PATTON, J.:

Response to injectable selenium and vitaminum $\mathrm{E}$ on reproductive performance of sows receiving a standard comercial diet. Can. J. Anim. Sci., 66 (1986), 1065-1068

CIERESZKO, A.; GLOGOWSKI, J.; STRZEŻEK, J.; DEMIANOWICZ, W.:

Low stability of aspartate aminotransferase activity in boars semen. Theriogenology 37 (1992), 12691281

DEMBIŃSKI, Z.; BRONICKI, M.; WANDURSKI, A.:

Influence of selenium supplement on the pigs reproduction. Medycyna Wet., Lublin, Poland, 48 (1992), 164-166

GABRYSZUK, M.:

The effect of selected minerals and vitamin E on the reproduction. Animal Sci. Papers and Reports., 12 (1994), 53-61

HEIMANN, E.D.; SMITH, M.F.; MORRIS, J.S.; GALL, T.J.; ELMORE, R.G.; MORROW, R.E.:

Relationships among spermatozoal anormalities and the selenium concentration of blood plasma, semen, and reproductive tissues in young bulls. Anim. Reprod. Sci., 7 (1984), 315-321

HENSON, M.C.; KATTESH, H.G.; HITCHCOCK, J.P.; KINCAID, S.A.:

The effects of dietary selenium on growth and selected reproductive parameters in young boars. Anim. Prod., 37 (1983), 401-407

KLEENE, K.C.:

The Mitochondrial Capsule Selenoprotein - a structural protein in the mitochondrial capsule of mammalian sperm. In: BURK, R.F. (eds.). Selenium in Biology and Human Health, Berlin: SpringerVerlag (1993), 135-149

KRSKA, P.; LAHUCKY, R.; KÜCHENMEISTER, U.; NÜRNBERG, K.; PALANSKA, O.; BAHELKA, I.; KUHN, G.; ENDER, K.:

Effects of dietary organic selenium and vitamin E supplementation on post mortem oxidative deterioration in muscle of pigs. Arch. Tierz., Dummerstorf, 44 (2001) 2, 193-201

LASOTA, B.

Relationships between the content of trace elements in semen and blood of boars and the biological value of semen used to artifical insemination. Rozprawy 212, Akademia Rolnicza w Szczecinie, 1-53.

LIU, C.H.; CHEN, Y.M.; ZHANG, J.Z.; HUANG, M.Y.; SU, Q.; LU, Z.H.; YIN, R.X.; SHAO, G.Z.; FENG, D.; ZHENG, P.L.:

Preliminary studies on influence of selenium deficiency to the developments of genital organs and spermatogenesis of infancy boars. Acta Vet. Zootech. Sin., 13 (1982), 73-77

MAHAN, D.C.; PARRETT, N.A.:

Evaluating the efficiacy of Se-enriched yeast and sodium selenite on tissue Se retention and serum glutathione peroxidase activity in grower and finisher swine. J. Anim. Sci., 75 (1996), 2994-3003

MARIN-GUZMAN, J.; MAHAN, D. C.; CHUNG, Y.K.; PATE, J.L.; POPE, W.F.: 
Effects of dietary selenium and vitamin E on boar performance and tissue responses, semen quality, and subsequent fertilization rates in mature gilts. J. Anim. Sci., 75 (1997), 2994-3003

MARIN-GUZMAN, J.; MAHAN, D.C.; PATE, J.L.:

Effect of dietary selenium and vitamin $\mathrm{E}$ on spermatogenic development in boars. J. Anim. Sci., 78 (2000a), 1537-1543

MARIN-GUZMAN, J.; MAHAN, D.C.; WHITMOYER, R.:

Effect of dietary selenium and vitamin $\mathrm{E}$ on the ultrastructure and ATP concentration of boar spermatozoa, and the efficiacy of added sodium selenite in extended semen on sperm motility. J. Anim. Sci., 78 (2000), 1544-1550

NATIONAL RESEARCH COUNCIL:

Nutrient Requirements of Swine, $10^{\text {th }}$ Ed., National Academy Press, Washington, D.C., (1998), 55

POLISH NORM OF PIGS NUTRITION:

The Institute Animal Physiology and Nutrition, PAN, Jabłonna, (1993), 1-87

PAGLIA, D.E.; VALENTINE, W.N.:

Studies on quantitative characterization of erytrocyte glutathione peroxidase. J. Lab. Clinical Med., 70 (1967), 158-169

PEHRSON, B.G.:

Selen in feeding: Bioavailability of organic and inorganic forms. Ann. Europ. Lecture Tour Alltech, Warszawa (1994), 55-76

PURSEL, V.G.; JOHNSON, L.A.; RAMPACEK, G.B.:

Acrosome morphology of boar spermatozoa incubated before cold shock. J. Anim. Sci., 34 (1972), 5564

SAARANEN, M.; SUISOMA, U.; VANA-PERTTULA, T.:

Semen selenium content and sperm mitochondrial volume in human and some animal species. Hum. Repr. Med., 4 (1989), 304-308

SCHILLING, E.; VENGUST, M.:

Frequency of semen collection in boars and quality of ejaculates as evaluated by the osmotic resistance of acrosomal membrane. Anim. Repr. Sci., 56 (1987), 1065-1076

SEGERSON, E.C.; GETZ, W.R.; JOHNSON, B.H.:

Selenium and reproductive function in boars fed a low selenium diet. J. Anim. Sci. 53 (1981), 13601367

SMITH, D.G.; SENGER, P.L.; MC CUTCHAN, J.F.; LANDA, C.A.:

Selenium and glutathion peroxidase distribution in bovine semen and selenium retention by the tissues of the reproductive tract in the bulls. Biol. Repr. 20 (1979), 377-383

UDAŁA, J.; RAMISZ, A.; DREWNOWSKI, W.; LASOTA, B.; RADOCH, W.:

The semen quality of bulls after application of selenium and vitamin E. Zesz. Nauk. AR Szczecin, 168 (1995), 57-63

UDAŁA, J.; KRASNOSIELSKA-WARCHOŁ, D.; ROZEN, J.; RADOŃ, W.:

The usefulness of osmotic resistance test (ORT) for evaluation of the fertilizing capability of boar semen. Zesz. Nauk. PTZ, Prz. Hod., 26 (1996), 83-90

WALLACE, E.; CALVIN, H.I.; COOPER, G.W.:

Progressive effects observed in mouse sperm during course of three generations of selenium deficiency. Gamete Res., 4 (1983), 377-387

WANDURSKI, A.:

A trial to use selenium in a prophylactic of the MMA syndrome. Medycyna Wet., Lublin, Poland, 46 (1990), 54-55

WATKINSON, J.H.:

Fluorometric determinations of selenium in biological material with 2,3, diaminonaphtalene. Anal. Chem., 38 (1966), 92-103

YOUNG, L.D.; LEYMASTER, K.A.; LUNSTRA, D.D.:

Genetic variation in testicular development and its relationship to female reproductive traits in swine. J. Anim. Sci., 63 (1986), 17-26

Received: 2004-02-09

Accepted: 2004-12-01

Author's address

ANITA KOŁODZIEJ, PhD, Prof. EUGENIA JACYNO, PhD DSc

Department of Pig Breeding, University of Agriculture

ul. Doktora Judyma 10

71-460 Szczecin

Poland

E-mail: A.Kolodziej@biot.ar.szczecin.pl 